\title{
Line Balancing and Layout Model for Productivity Improvement in Leather Footwear Industry
}

\author{
Sisay Addis \\ School of Mechanical and Industrial Engineering, Institute of Technology, \\ Debre Markos University, P.O.B. 269, Debre Markos, Ethiopia
}

\begin{abstract}
The government of Ethiopia considers the leather footwear industry as one of the priority sector that is capable of accelerating economic development by creating more employment opportunities. However, the industry's contribution to the national economy so far is not enjoyable as productivity of the industry is much lower qualitatively, quantitatively and value-wise. The focal constraint against performance of the industry is the existence of bottleneck process in the production line. The major ones are pile up of 'UPPER' (i.e. upper part of a shoe) at some points, because of unequal workload distribution among workstations. Accordingly, the main objective of this study is to improve the production line efficiency through line balancing technique that is demonstrated by taking Peacock shoe factory as a case study. The study considered 'Bades shoe model' to investigate the production line in the Stitching department. Data were collected through direct data intake from the shop-floor activities and company's database. A well-prepared templates and stopwatch were used for the data collection. The analysis was carried out through the logic of modular system. This system uses work sharing method in which cross-trained workers perform multiple tasks to eliminate bottleneck processes and balance workloads among workstations. Furthermore, the study proposed a layout model to balance the production line. The results suggest that the production line efficiency is improved from $68.89 \%$ to $87.6 \%$, and the labor productivity is increased from 16.67 to 23.44 . The findings provide important insights into productivity improvements by creating smooth flow of components in assembly lines.
\end{abstract}

Keywords: Ethiopia, leather footwear, bottleneck process, line balancing.

DOI: $10.7176 /$ IEL/10-2-03

Publication date:March $31^{\text {st }} 2020$

\section{Introduction}

The tannery operation consists of converting the raw skin (a highly putrescible material) into leather (a stable material). The leather material is used for the manufacturing of a wide range of products like footwear, leather cloth, general goods, etc. The orientation of finishing tanneries has altered over the last few decades. Nowadays, tanneries produce leather material mainly for footwear, garments, general goods, furniture manufacturers and automotive upholstery manufacturers. Of which, the footwear subsector has grown considerably fast. About $65 \%$ of the world production of leather is estimated to go into leather footwear production (Netsanet 2014). The production of leather footwear plays a considerable role in the development process of both developing and developed countries (Ulutas and Islier 2015). The total export of leather footwear in the world is US \$47 billion. China is the leading exporter of footwear with total market share of $22 \%$ followed by Italy, which accounts a value of $15 \%$. Vietnam, Hong Kong, Germany and Belgium follow with footwear export share of 8\%, 7.8\%, 4.4\%, and $3.9 \%$, respectively. On the contrary, Africa's share of footwear export is mere $1.3 \%$ (LIDI 2012). In general, the total production of leather and leather products in Africa is much lower qualitatively, quantitatively and value-wise (Mwinyihija 2014). Seizing the global market opportunities has remained the key challenge, irrespective of having large resource endowment to satisfy raw material needs. Africa contains $21 \%$ of the livestock population in the world (UNIDO 2010). Reducing the gap between resources and production is critical for the development of the leather-processing countries in Africa. Ethiopia is one of the leading leather processing countries in Africa (Addis et al. 2019). The leather industry in Ethiopia puts at the forefront of the African leather sector in line with its current comparative advantage for the raw material needs. Availability of large livestock population constituted the country's comparative advantages for the development of leather sector in Ethiopia. Ethiopia has the major comparative advantage to satisfy global raw material requirements (1st in Africa and 10th in the world in livestock population) (UNIDO 2010). The livestock population growth trend (cattle, sheep and goat) also shows potential of the sector to be the main economic source of the country in the future. The livestock population escalated from 54.5 million in $1995 / 96$ to 77.5 million in $2005 / 06$ to 103.5 million in 2012/13 (Leta and Mesele 2014). This resource potential makes the leather industry to be a good candidate for a concerted effort to expand production and achieve competitiveness at the international level.

Despite the above mentioned indigenous resource potentials, the leather industry of Ethiopia is yet to utilize its resources to appreciable extent (Addis 2019). It significantly lags behind many countries that are less abundantly endowed with their indigenous resources (Netsanet 2014). The tannery and footwear producers operate at $44.97 \%$ and $47.6 \%$ of the daily production capacity, respectively. For the period of $2005-2009$, footwear producers 
performed, on average, only $27.55 \%$ of the planned export value (LIDI 2012). Also, actual average production of the footwear industry is far below the international benchmark standards. For instance, in 2009, the footwear producing companies perform 4 pairs of shoe/day/person, which characterized low operational performance and production efficiency as compared to best practices (i.e. 16 pairs of shoe/day/person) (Cherkos 2011). Studies revealed that the industry faces serious problems, both in the production of raw materials and in the manufacturing stages (Addis et al. 2017b). Addressing constraints downstream to the manufacturing stage is critical, because higher stage of manufacturing activity enable organizations achieve increased level of operational performances (Addis, et al. 2017a). One of the focal constraint against the productivity of footwear industries is bottleneck process in the production line, which results in long production lead times (Addis, et al. 2017a). Bottleneck operations are recognized as having a relentless impact on the operational performance of the footwear manufacturing organizations in Ethiopia. Bottleneck creates a queue and a longer overall cycle time. This study considered Peacock shoe factory as a case study. Peacock shoe factory, one of footwear manufacturer engaged in production of Ladies' shoes and Men's shoes, faces problems in the production line. Among many problems, the major ones are pile up of 'UPPER' (i.e. upper part of a shoe) at some workstations, because of unequal workload distribution among workstations. There are bottlenecks at some stations and low utilization of the production lines. Moreover, some stations have higher utilization as compared to others. When extra UPPER is piled up at a workstation, the supervisor shifts operators from another workstation to balance the system. This process happens every now and then. To solve the problem, there is a need to optimize the distribution of workloads among workstation, reduce production cycle time and maximize the output/productivity. Accordingly, the main objective of this study is to improve the production line efficiency through line balancing technique that is demonstrated by taking Peacock shoe factory as a case study.

The rest of the paper has been organized as follows. Sections 2 presents the concept of line balancing. Section 3 presents the methodology, followed by data analysis in Section 4. Subsequently, results of the study and conclusions are presented in Section 5 and Section 6, respectively.

\section{Line Balancing Concept}

A line is defined as a group of operators under the control of production supervisors. Balancing refers to the procedures of adjusting the operation times at work centers to conform as much as possible to the required cycle time and production target. Line balancing is defined as the appointment of sequential work activities into workstations in order to gain a high utilization of labor and equipment and therefore minimize idle time. The line balancing is concerned with assigning the individual work elements so that all workers have an equal amount of work (Kitaw et al. 2010). The objective of line balancing is to balance the workload of each operation to make sure that the flow of work is smooth, that no bottlenecks are created, and operators are able to work at peak performance throughout the day. Line balancing is a way to minimize imbalance workloads between workers to achieve the desired output. Balancing may be achieved by rearrangement of the workstations or by adding machines and workers at some of work stations. This process is intended to reduce waiting time to a minimum, and try to equalize standard time of each operation. A balanced process is one where the actual cycle times at every stage are equal. The line balancing is important to enable better production planning and schedule, enable operators to work at optimal pace, and keep inventory cost low (Agarwal et al. 2019).

\section{Methodology}

Peacock shoe factory manufactures a variety of shoe models. This study has considered a specific type of shoe model, i.e. 'Bades shoe model' to investigate the production line. The raw material, mainly leather, is processed in different departments such as cutting, stitching and lasting departments. In this study, the Stitching department is considered as it is the largest and most important department in the footwear production. Operations involved in the stitching department significantly determines the whole speed of the leather components assembly in the company. The study has been conducted by comparing the productivity and efficiency before and after applying the line balancing technique. The time to make each process has been recorded, and standard pitch time and capacity for workstations have been determined. A stopwatch was used to record operation times. To find out the standard allowable minute (SAM) value, process wise capacity has been calculated. In addition, the labor productivity and line efficiency are calculated. The production line has been balanced considering the "bottleneck processes" and "balancing processes", where the balancing process shared some jobs of the bottleneck process. After balancing, new manpower has been proposed and final capacity of each worker has been reallocated. The study also proposed production layout model that has been modeled with the balanced capacity of each workstation.

\section{Data Analysis}

The study has been conducted by comparing the productivity and efficiency before and after applying the line balancing technique. 


\subsection{Before Line Balancing}

The processing time has been recorded to find out the number of operators, SAM and process wise capacity. Process capacity was determined using the working time available in a day i.e. $8 \mathrm{hr}$ or $480 \mathrm{~min}=28800 \mathrm{sec}$. For instance, the 'Stamping on lining' operation has a standard time of 13.90 second. Thus, capacity/day is $28800 \mathrm{sec} / 13.90 \mathrm{sec}=2071 \mathrm{units} /$ day. Similarly, the process capacity is determined for all the operations. Process wise capacity of each work station is presented in Annexure 1. Table 1 presents the total output/day, a total number of manpower on the production line and a daily working time with a S.A.M value of 20 . The study standardized the benchmark target of 750 pair of shoes/day. The benchmark target was set considering the bottleneck problem that is responsible for the total production line efficiency. From the capacity determination, each workstation is possible to upgrade the target daily production to 750 (see Annexure 1). Observation before the line balancing showed that labor productivity and line efficiency as 16.67 and $69.44 \%$, respectively (see Table 1). Both are calculated using equation (1) and equation (2), respectively. Plotting process wise capacity in a line graph shows the variation of each process from the benchmark target as the upper capacity is 2277 pieces/day and the lower capacity is only 407 pieces/day compare to the benchmark target of 750 pieces/day. The process capacity before the line balancing is shown in Figure 1. It can be revealed from figure 1 that there is an imbalance situation and existence of bottleneck throughout the workstations in the stitching department.

- $\quad$ Labor productivity $=$ Total number of output per day per line/number of

$$
\text { workers }
$$

- $\quad$ Line efficiency $=$ Total output/day $*$ S.A.M / (total manpower/line $*$ total working minutes/day)*100\%..(2)

\subsection{Line Balancing}

The production line has been balanced considering the bottleneck processes and balancing process where the balancing process has shared the excess time to the bottleneck process. The basic objective of line balancing is to achieve efficient utilization of manpower. The classical industrial engineering studies of line balancing considers the logic of modular system that shifts work or workers from one station to another to balance the load (Gel et al. 2002). In the traditional system, one worker is eligible to perform one process. The present study followed the logic of modular system (one worker perform more than one operations). In such cases, a series of skilled crosstrained workers are required to perform multiple tasks and to achieve more productivity. On this occasion, skilled workers are eligible for the production processes and proper training is essential to achieve the optimum improvements on productivity and efficiency.

Bottleneck processes

Variations in the process capacity of the different workstations (WS) have been revealed in Figure 1. WSs with the lower capacity compared to the benchmark target is the bottleneck process as production flow would stuck on these stations. 11 bottleneck WSs have been identified. These are Back seam stitching and Upper quarter stitching, Foam attachment on vamp, lining attaching on upper and lining attaching on apron, Glue app. on quarter lining, lasting margin stitch (vamp), Counter stiffener and lining attach, Elastic stitch on quarter, Thread burning and cleaning, Counter molding and Vamp zigzag stitch, Thread burning and cleaning and Strap stitch one. The total production line has been blocked in these 11 WSs and large work-in-process (WIP) are stuck in these bottleneck stations.

\section{Balancing Processes}

Balancing method is very essential to make the production flow smoother, by eliminating the bottleneck WSs. The logic of modular system allows workers, who have extra time after completing their works, to help and complete the bottleneck processes. The 11 bottleneck WSs are presented in the left side of Table 2. Worker who is working in Process no. 1 takes $7.38 \mathrm{hr}$ to completed his/her daily job and then help process no. 2 for last 22 minutes. Process no. 3 takes $7.39 \mathrm{hr}$ to completed his/her daily job and then help process no. 4 for last 21 minutes. Similarly, workers who are working on process no.5, $8,10,13,12,16,18,19$, and 22 are required to help process no.7, 6, 9, 11, 15, 17, 14, 21 and 23, respectively. Now, each of WSs has almost a balanced workload through the combination of balancing and bottleneck processes, and operators are able to work at peak performance throughout the day (see Table 2).

\subsection{Proposed Layout}

The proposed layout model in Figure 2 shows that the processes in the production line are almost balanced through the combination of balancing and bottleneck processes. The Proposed layout model followed the logic of modular system (one worker works more than one processes who is skilled on all processes and these combination of skilled workers finish their work in piece flow production). The blue arrow on the center table indicates the production flow through the process no. and green arrow shows the sharing of works in between balancing and bottleneck processes. First column on both side of center table shows the WSs and then followed by process no. process name, S.A.M value, previous capacity and capacity after balancing. After the first process, i.e. stamping on lining and re- 
enf. attachment on counter, bundle of leather components come to process no. 2, i.e. Back seam stitching and Upper quarter stitching, then the bundle passes horizontally to process no. 3 and so on. From process no. 1 to 2 and process no. 8 to 6 , work flows vertically with short distance for balancing out the possible processes of no. 2 and 6. Similarly, for balancing 11 stations, the short possible distance can be used that makes the total production time minimum.

\section{Result}

Changing from traditional layout to balanced layout model results in improvements in manpower utilization and the total production efficiency. The total number of workers in stitching department were reduced from 42 to 32 (see Annexure 1), labor productivity has been increased from 16.67 to 23.44 and has been improved from $68.89 \%$ to $87.6 \%$. The production capacity can be boost up to 750/day with manpower of 32 (see Table 3). After balancing the process flow, figure- 3: shows less variation of each process from the benchmark target. It reflects a balanced flow in the production line.

\section{Conclusion}

In this study, the aim was to improve the productivity of a leather footwear manufacturing company by using a line balancing technique and standardization of work through a layout model. The real problem is identified and it is found to be associated with the line balancing and standardization. Line balancing was conducted and process flow is analyzed thoroughly. The production line has been balanced considering the 'bottleneck processes' and 'balancing process', where the balancing process shared the excess time to the bottleneck process. The layout model also provided efficient arrangement of workstations to create smooth flow of components in the production line. The results showed that the production line efficiency of the company is improved from $68.89 \%$ to $87.6 \%$, and the labor productivity is increased from 16.67 to 23.44 . It is also revealed that the total number of workers were reduced from 42 to 32 .

\section{REFERENCES}

Addis S, Dvivedi A, Beshah B (2017a) Identifying and prioritising operational performance indicators of the Ethiopian leather industry. Int J of Prod and Qual Manag, 22(3): 378-394.

Addis S, Dvivedi A, Beshah B (2017b) Decision-making on job satisfaction improvement programmes using fuzzy QFD model: a case study in Ethiopia. Total Qual Manag \& Bus Excel, 30(9-10): pp. 1-24, available at: http://dx.doi.org/10.1080/14783363.2017.1354693

Addis S, Dvivedi A, Beshah B (2019) Quality management practices as a tool for job satisfaction improvement of shop-floor workers: empirical evidence from the Ethiopian manufacturing organizations. Prod Plan \& Control, 30(8): 665-681, doi: 10.1080/09537287.2019.1574510.

Addis S (2019) An exploration of quality management practices in the manufacturing industry of Ethiopia. The TQM Journal. DOI 10.1108/TQM-01-2019-0031.

Agarwal R, Bagul D, Agey C, Ayare P (2019) Basic Study of Assembly Line Balancing. Int Res J of Eng and Techn (IRJET), 06(04): 2627- 2630

Cherkos T. (2011). Performance Analysis and Improvement of Ethiopian Leather Footwear Factories: With Special Reference to Anbessa Shoe SC. MSc. Thesis, AAU, Ethiopia.

Gel E, Hopp W, Van Oyen M. (2002) Factors affecting opportunity of worksharing as a dynamic line balancing mechanism. IIE Transactions, 34(10): 847-863.

Jote N. (2014). Impact of Supply Chain and Industrial Cluster on the Competitive Advantage of Ethiopian Leather Sector. Ph.D. Thesis, AAU, Ethiopia.

Kitaw D, Matebu A, Tadesse S (2010) Assembly Line Balancing Using Simulation Technique in A Garment Manufacturing Firm. Journal of EEA, 27.

Leta S. and Mesele F. (2014) Spatial analysis of cattle and shoat population in Ethiopia: growth trend, distribution and market access. Springer Plus, 3(1), 310.

LIDI, Value chain analysis on leather garment \& goods sub sector in Ethiopia, unpublished report, Addis Ababa, Ethiopia, 2012.

Mwinyihija M. and Quiesenberry W. (2013) Review of the challenges towards value addition of the leather sector in Africa. Global advanced res J of Manag and Bus studies, 2(11), 518-528.

Mwinyihija M. (2014) Emerging World Leather Trends and Continental Shifts on Leather and Leather goods Production. Advances in Business Management and Administration, 1(1), 001-013.

Mekonnen B. and Gezahegn A. (2008). The Leather Sector: Growth strategies through Integrated Value Chain. Ethiopian Development Research Institute, Addis Ababa, Ethiopia.

Mengstu A. (2014). Performance of Leather Uppers of Local Footwear products and the Determinants. International J of Adv in Res \& Tech, 3(3).

Netsanet J. P. (2014) Impact of Supply Chain and Industrial Cluster on the Competitive Advantage of Ethiopian 
Leather Sector. Disseration, AAU, Ethiopia.

Ulutas B. and Islier A. (2015) Dynamic facility layout problem in footwear industry. J of Manuf Systems, 36: 55 61.

UNIDO (2010) Future trends in the world leather and leather products industry and trade. https://leatherpanel.org/ assessed 13 July 2018.

Annexure 1: Capacity determination for stitching department

\begin{tabular}{|c|c|c|c|c|c|c|c|c|c|c|}
\hline \multicolumn{5}{|c|}{ Actual capacity and actual no. of workers } & \multirow[b]{2}{*}{ Remark } & \multicolumn{5}{|c|}{$\begin{array}{l}\text { Proposed capacity and no. of workers } \\
\text { (Target 750) }\end{array}$} \\
\hline $\begin{array}{l}\text { Sr. } \\
\text { No. }\end{array}$ & $\begin{array}{l}\text { Operations } \\
\text { in sequence }\end{array}$ & $\begin{array}{l}\text { Std. } \\
\text { time }\end{array}$ & Capacity/day & $\begin{array}{l}\text { No. of } \\
\text { worker }\end{array}$ & & S.No & $\begin{array}{l}\text { Operations in } \\
\text { sequence }\end{array}$ & S.A.M & $\begin{array}{l}\text { No. of } \\
\text { worker }\end{array}$ & Capacity/day \\
\hline 1 & $\begin{array}{l}\text { Stamping on } \\
\text { lining }\end{array}$ & 13.90 & 2071 & 1 & \multirow[b]{2}{*}{$\begin{array}{l}\text { Club together } \\
\text { and assist } \\
\text { operation } 2\end{array}$} & \multirow[t]{2}{*}{1} & \multirow{2}{*}{$\begin{array}{l}\text { Stamping on lining } \\
\text { and Re-enf. } \\
\text { attachment on } \\
\text { counter }\end{array}$} & & \multirow[t]{2}{*}{1} & \multirow[b]{2}{*}{753} \\
\hline 2 & $\begin{array}{l}\text { Re-enf. } \\
\text { attachment } \\
\text { on counter }\end{array}$ & 23.89 & 1205 & 1 & & & & 0.588 & & \\
\hline 3 & $\begin{array}{l}\text { Back seam } \\
\text { stitching }\end{array}$ & 20.21 & 1425 & 1 & & 2 & $\begin{array}{l}\text { Back seam stitching } \\
\text { and Upper quarter } \\
\text { stitching }\end{array}$ & 0.667 & & 753 \\
\hline 4 & $\begin{array}{l}\text { Upper } \\
\text { quarter } \\
\text { stitching } \\
\end{array}$ & 20.24 & 1423 & 1 & Club together & & & & 1 & \\
\hline 5 & $\begin{array}{l}\text { Lining } \\
\text { quarter } \\
\text { stitching }\end{array}$ & 18.77 & 1534 & 1 & \multirow{2}{*}{$\begin{array}{l}\text { Club together } \\
\text { and assist } \\
\text { operation } 7\end{array}$} & \multirow[t]{2}{*}{3} & \multirow[t]{2}{*}{$\begin{array}{l}\text { Lining quarter } \\
\text { stitching and } \\
\text { Hammering }\end{array}$} & \multirow[t]{2}{*}{0.572} & \multirow[t]{2}{*}{1} & \multirow[t]{2}{*}{775} \\
\hline 6 & Hammering & 17.71 & 1626 & 1 & & & & & & \\
\hline 7 & $\begin{array}{l}\text { Foam } \\
\text { attachment } \\
\text { on vamp }\end{array}$ & 79.12 & 728 & 2 & & 4 & $\begin{array}{l}\text { Foam attachment on } \\
\text { vamp }\end{array}$ & 0.645 & 2 & 760 \\
\hline 8 & $\begin{array}{l}\text { Foam } \\
\text { attaching on } \\
\text { apron }\end{array}$ & 74.2 & 776 & 2 & & 5 & $\begin{array}{l}\text { Foam attaching on } \\
\text { apron }\end{array}$ & 0.591 & 2 & 760 \\
\hline 9 & $\begin{array}{l}\text { Glue app. on } \\
\text { quarter } \\
\text { lining }\end{array}$ & 80.24 & 718 & 2 & & 6 & $\begin{array}{l}\text { Glue app. on quarter } \\
\text { lining }\end{array}$ & 0.654 & 2 & 751 \\
\hline 10 & $\begin{array}{l}\text { Lining } \\
\text { attaching on } \\
\text { upper }\end{array}$ & 15.07 & 1911 & 1 & \multirow[b]{2}{*}{$\begin{array}{l}\text { Club together } \\
\text { and assisted } \\
\text { from } \\
\text { operation } 8\end{array}$} & \multirow[t]{2}{*}{7} & \multirow[t]{2}{*}{$\begin{array}{l}\text { Lining attaching on } \\
\text { upper and lining } \\
\text { attaching on apron }\end{array}$} & \multirow[t]{2}{*}{0.654} & \multirow[t]{2}{*}{1} & \multirow[t]{2}{*}{755} \\
\hline 11 & $\begin{array}{l}\text { lining } \\
\text { attaching on } \\
\text { apron }\end{array}$ & 14.72 & 1957 & 1 & & & & & & \\
\hline 12 & Vamp re-cut & 19.04 & 1513 & 1 & \multirow{2}{*}{$\begin{array}{l}\text { Club together } \\
\text { and assist } \\
\text { operation } 9\end{array}$} & \multirow[t]{2}{*}{8} & \multirow[b]{2}{*}{$\begin{array}{l}\text { Vamp re-cut and } \\
\text { Apron re-cut }\end{array}$} & \multirow[t]{2}{*}{0.586} & & \multirow[t]{2}{*}{756} \\
\hline 13 & Apron re-cut & 17.38 & 1657 & 1 & & & & & 1 & \\
\hline 14 & $\begin{array}{l}\text { Lasting } \\
\text { margin stitch } \\
\text { (vamp) }\end{array}$ & 39.71 & 725 & 1 & & 9 & $\begin{array}{l}\text { Lasting margin stitch } \\
\text { (vamp) }\end{array}$ & 0.661 & 1 & 760 \\
\hline 15 & $\begin{array}{l}\text { Marking on } \\
\text { vamp }\end{array}$ & 36.22 & 795 & 1 & $\begin{array}{l}\text { Assist } \\
\text { operation } 14\end{array}$ & 10 & Marking on vamp & 0.582 & 1 & 760 \\
\hline 16 & $\begin{array}{l}\text { Counter } \\
\text { stiffener and } \\
\text { lining attach }\end{array}$ & 39.21 & 734 & 2 & & 11 & $\begin{array}{l}\text { Counter stiffener and } \\
\text { lining attach }\end{array}$ & 0.653 & 1 & 757 \\
\hline 17 & $\begin{array}{l}\text { Counter } \\
\text { stitch with } \\
\text { vamp }\end{array}$ & 70.76 & 407 & 1 & $\begin{array}{l}\text { Assist } \\
\text { operation } 21\end{array}$ & 12 & $\begin{array}{l}\text { Counter stitch with } \\
\text { vamp }\end{array}$ & 0.571 & 2 & 760 \\
\hline 18 & Trimming & 36.59 & 787 & 1 & $\begin{array}{l}\text { Assist } \\
\text { operation } 16\end{array}$ & 13 & Trimming & 0.585 & 1 & 764 \\
\hline 19 & $\begin{array}{l}\text { Counter } \\
\text { molding }\end{array}$ & 18.23 & 1579 & 1 & \multirow{2}{*}{$\begin{array}{l}\text { Club together } \\
\text { and assisted } \\
\text { from } \\
\text { operation } 24\end{array}$} & \multirow[t]{2}{*}{14} & \multirow[t]{2}{*}{$\begin{array}{l}\text { Counter molding and } \\
\text { Vamp zigzag stitch }\end{array}$} & \multirow[t]{2}{*}{0.654} & \multirow[t]{2}{*}{1} & 756 \\
\hline 20 & $\begin{array}{l}\text { Vamp } \\
\text { zigzag stitch }\end{array}$ & 21.68 & 1328 & 1 & & & & & & \\
\hline 21 & $\begin{array}{l}\text { Elastic stitch } \\
\text { on quarter }\end{array}$ & 41.07 & 701 & 1 & & 15 & $\begin{array}{l}\text { Elastic stitch on } \\
\text { quarter }\end{array}$ & 0.683 & 1 & 755 \\
\hline 22 & Apron stitch & 35.13 & 822 & 1 & $\begin{array}{l}\text { Assist } \\
\text { operation } 23\end{array}$ & 16 & Apron stitch & 0.567 & 1 & 755 \\
\hline 23 & $\begin{array}{l}\text { Thread } \\
\text { burning and } \\
\text { cleaning }\end{array}$ & 84.14 & 684 & 2 & & 17 & $\begin{array}{l}\text { Thread burning and } \\
\text { cleaning }\end{array}$ & 0.669 & 2 & 751 \\
\hline 24 & $\begin{array}{l}\text { Bind tape } \\
\text { attaching }\end{array}$ & 36.73 & 784 & 1 & & 18 & Bind tape attaching & 0.587 & 1 & 761 \\
\hline 25 & $\begin{array}{l}\text { Bind } \\
\text { stitching }\end{array}$ & 35.55 & 810 & 1 & $\begin{array}{l}\text { Assist } \\
\text { operation } 27\end{array}$ & 19 & Bind stitching & 0.571 & 1 & 770 \\
\hline 26 & $\begin{array}{l}\text { Binding } \\
\text { trimming }\end{array}$ & 76.42 & 753 & 2 & & 20 & Binding trimming & 0.636 & 2 & 753 \\
\hline
\end{tabular}




\begin{tabular}{|c|c|c|c|c|c|c|c|c|c|c|}
\hline \multicolumn{5}{|c|}{ Actual capacity and actual no. of workers } & \multirow[b]{2}{*}{ Remark } & \multicolumn{5}{|c|}{$\begin{array}{l}\text { Proposed capacity and no. of workers } \\
\text { (Target 750) }\end{array}$} \\
\hline $\begin{array}{l}\text { Sr. } \\
\text { No. }\end{array}$ & $\begin{array}{l}\text { Operations } \\
\text { in sequence }\end{array}$ & $\begin{array}{l}\text { Std. } \\
\text { time }\end{array}$ & Capacity/day & $\begin{array}{l}\text { No. of } \\
\text { worker }\end{array}$ & & S.No & $\begin{array}{l}\text { Operations in } \\
\text { sequence }\end{array}$ & S.A.M & $\begin{array}{l}\text { No. of } \\
\text { worker }\end{array}$ & Capacity/day \\
\hline 27 & $\begin{array}{l}\text { Thread } \\
\text { burning and } \\
\text { cleaning }\end{array}$ & 23.11 & 1246 & 2 & & 21 & $\begin{array}{l}\text { Thread burning and } \\
\text { cleaning }\end{array}$ & 0.632 & 1 & 760 \\
\hline 28 & $\begin{array}{l}\text { Strap } \\
\text { Folding }\end{array}$ & 35.98 & 820 & 1 & $\begin{array}{l}\text { Assist } \\
\text { operation } 29\end{array}$ & 22 & Strap Folding & 0.568 & 1 & 751 \\
\hline 29 & $\begin{array}{l}\text { Strap stitch } \\
\text { one }\end{array}$ & 42.01 & 685 & 1 & & 23 & Strap stitch one & 0.7 & 1 & 754 \\
\hline 30 & $\begin{array}{l}\text { Strap } \\
\text { attachment }\end{array}$ & 17.72 & 1625 & 1 & \multirow[b]{2}{*}{ Club together } & \multirow[t]{2}{*}{24} & \multirow[t]{2}{*}{$\begin{array}{l}\text { Strap attachment and } \\
\text { Strap stitch two }\end{array}$} & \multirow[t]{2}{*}{0.608} & \multirow[t]{2}{*}{1} & \multirow[t]{2}{*}{789} \\
\hline 31 & $\begin{array}{l}\text { Strap stitch } \\
\text { two }\end{array}$ & 18.77 & 1534 & 1 & & & & & & \\
\hline 32 & $\begin{array}{l}\text { Jewelry } \\
\text { attach }\end{array}$ & 13.78 & 2090 & 1 & \multirow[b]{2}{*}{ Club together } & \multirow[t]{2}{*}{25} & \multirow[t]{2}{*}{$\begin{array}{l}\text { Jewelry attach and } \\
\text { Foam attaching }\end{array}$} & \multirow[t]{2}{*}{0.635} & \multirow[t]{2}{*}{1} & \multirow[t]{2}{*}{756} \\
\hline 33 & $\begin{array}{l}\text { Foam } \\
\text { attaching }\end{array}$ & 24.30 & 1185 & 1 & & & & & & \\
\hline 34 & $\begin{array}{l}\text { Socks } \\
\text { stitching }\end{array}$ & 16.49 & 1747 & 1 & \multirow{3}{*}{ Club together } & \multirow[t]{3}{*}{26} & \multirow[t]{2}{*}{$\begin{array}{l}\text { Socks stitching and } \\
\text { Inspection }\end{array}$} & & & \multirow[t]{2}{*}{800} \\
\hline 35 & Inspection & 12.65 & 2277 & 1 & & & & 0.585 & 1 & \\
\hline Tota & & & & 42 & & & & & 32 & \\
\hline
\end{tabular}

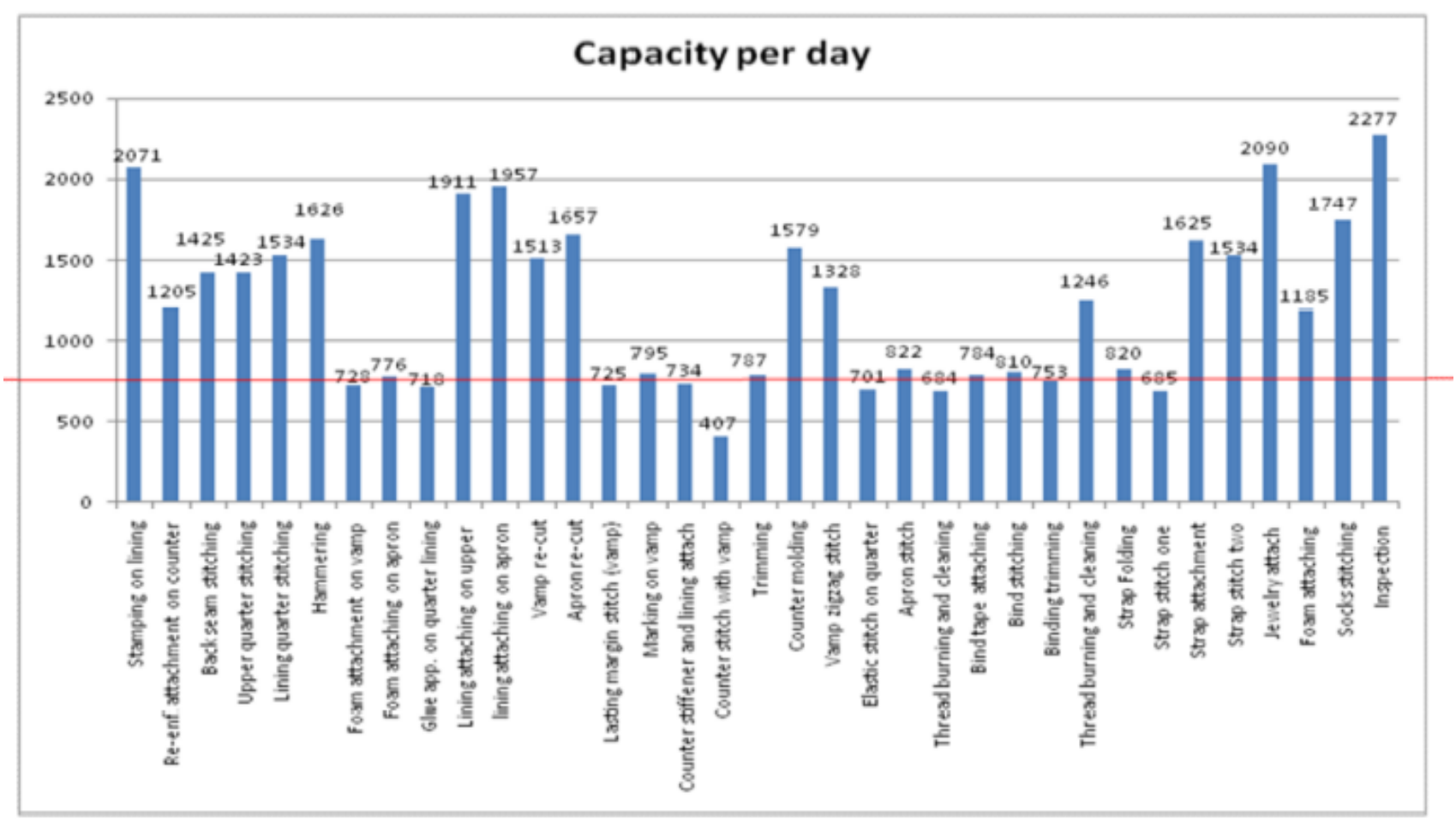

Figure 1. Variations in process capacity with respect to the benchmark target (i.e. 750 pieces/day) 


\begin{tabular}{|c|c|c|c|c|c|c|c|c|c|c|}
\hline $\begin{array}{c}\text { Balanced } \\
\text { Capacity } / \mathrm{hr} \text {. }\end{array}$ & $\begin{array}{l}\text { Previous } \\
\text { capacity }\end{array}$ & S.A.M. & $\begin{array}{c}\text { Process } \\
\text { no. }\end{array}$ & \multicolumn{3}{|c|}{ Table } & $\begin{array}{c}\text { Process } \\
\text { no. }\end{array}$ & S.A.M & $\begin{array}{l}\text { Previous } \\
\text { capacity }\end{array}$ & $\begin{array}{c}\text { Balanced } \\
\text { Capacity } / \mathrm{hr} \text {. }\end{array}$ \\
\hline 753 & 776 & 0.588 & 1 & $\mathrm{WS}_{1}$ & & & & & & \\
\hline 753 & 720 & 0.667 & 2 & $\mathrm{WS}_{2}$ & $\downarrow$ & $\mathrm{WS}_{3}$ & 3 & 0.572 & 807 & 775 \\
\hline 760 & 776 & 0.591 & 5 & $\begin{array}{c}\mathrm{WS}_{5} \\
\text { (2 person) }\end{array}$ & & $\begin{array}{c}\mathrm{WS}_{4} \\
\text { (2 person) }\end{array}$ & 4 & 0.645 & 7728 & 760 \\
\hline 755 & $739 \nabla$ & 0.654 & 7 & $\mathrm{WS}_{7}$ & & $\mathrm{WS}_{6}$ & 6 & 0.654 & $\begin{array}{r}718 \\
\end{array}$ & 751 \\
\hline 760 & 725 & 0.661 & 9 & $\mathrm{WS}_{9}$ & & $\mathrm{WS}_{8}$ & 8 & 0.586 & 789 & 756 \\
\hline 760 & 795 & 0.582 & 10 & $\mathrm{WS}_{10}$ & 1 & $\mathrm{WS}_{11}$ & 11 & 0.653 & 4734 & 757 \\
\hline 760 & 814 & 0.571 & 12 & $\begin{array}{c}\mathrm{WS}_{12} \\
\text { (2 person) }\end{array}$ & & $\mathrm{WS}_{13}$ & 13 & 0.585 & 787 & 764 \\
\hline 755 & 701 & 0.683 & 15 & $\mathrm{WS}_{15}$ & & $\mathrm{WS}_{14}$ & 14 & 0.654 & $\begin{array}{r}733 \\
\end{array}$ & 756 \\
\hline 755 & 822 & 0.567 & 16 & $\mathrm{WS}_{16}$ & & & & & & \\
\hline 751 & $684 \nabla$ & 0.669 & 17 & $\mathrm{~W}_{17}$ & & $\mathrm{WS}_{18}$ & 18 & 0.587 & 784 & 761 \\
\hline 753 & 753 & 0.636 & 20 & $\begin{array}{c}\mathrm{WS}_{20} \\
\text { (2 person) }\end{array}$ & & $\mathrm{WS}_{19}$ & 19 & 0.571 & 810 & 770 \\
\hline 751 & 820 & 0.568 & 22 & $\mathrm{~W}_{22}$ & & $\mathrm{WS}_{21}$ & 21 & 0.632 & 720 & 760 \\
\hline 754 & $685 \nabla$ & 0.7 & 23 & $W_{23}$ & & $\mathrm{WS}_{24}$ & 24 & 0.608 & 789 & 789 \\
\hline 800 & 800 & 0.585 & 26 & $\mathrm{WS}_{26}$ & $\longleftarrow$ & $\mathrm{WS}_{25}$ & 25 & 0.635 & 756 & 756 \\
\hline
\end{tabular}

WS $=$ Work Station

Figure 2. Proposed layout model to balance the bottleneck processes.

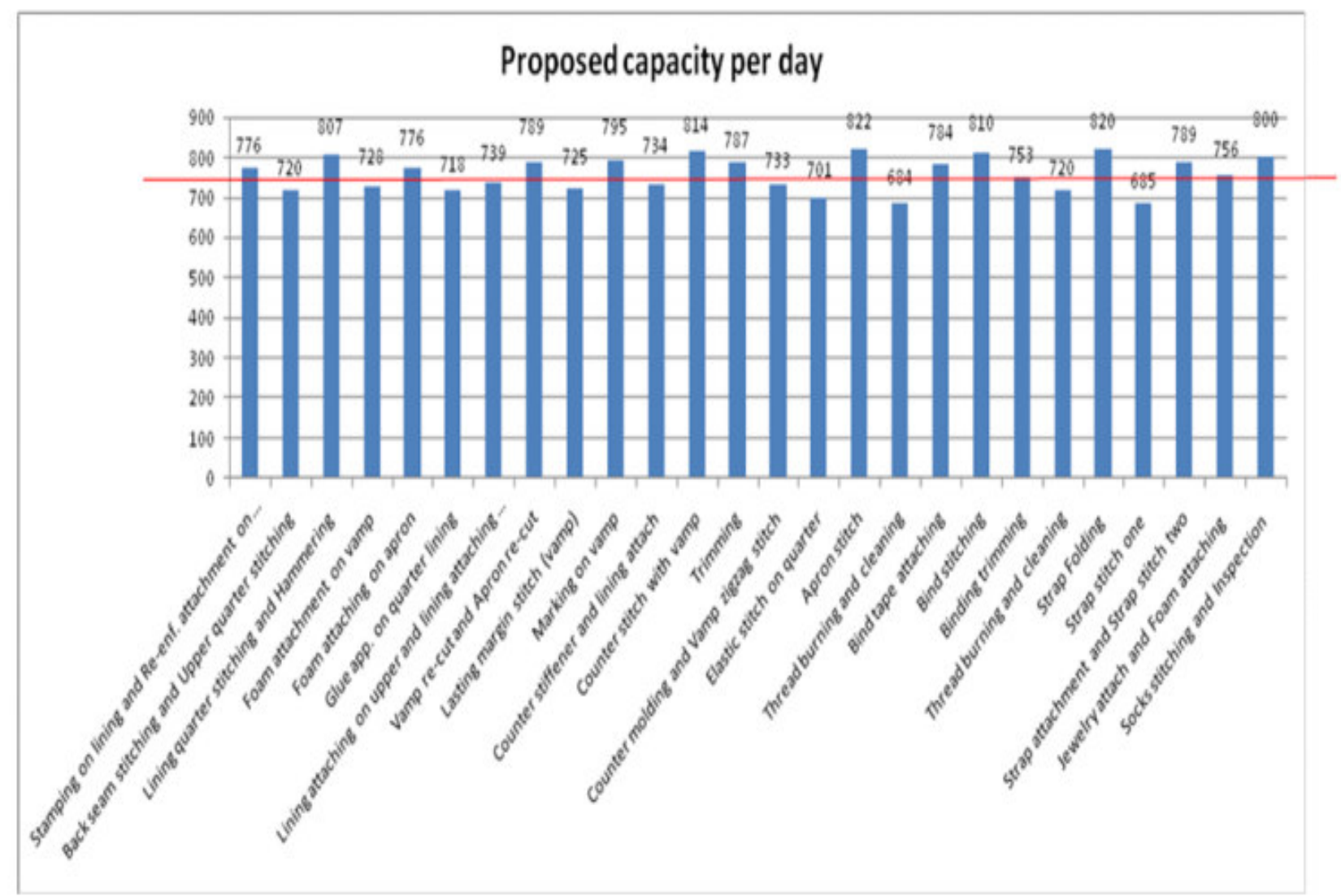

Figure 3. Variation in each process capacity per day compare to benchmark target per day 
Table 1. Line Efficiency and Labor productivity for Bades shoe model

\begin{tabular}{|l|l|l|}
\hline Total Output Per Day & 700 & \\
Total Manpower = & 42 & \\
Working Time $=$ & 480 Minute & \\
S.A.M $=$ & $20 \mathrm{~min}$ & Benchmark \\
\hline Target /day $=$ & 750 & \\
\hline Labor Productivity $=$ & 16.67 & \\
\hline Line Efficiency $\%=$ & 68.89 & \\
\hline
\end{tabular}

Table 2. Balancing Processes to equalize the bottleneck process

\begin{tabular}{|c|c|c|c|c|c|c|c|c|}
\hline \multirow[t]{2}{*}{ S.No. } & \multicolumn{4}{|c|}{ Bottleneck process } & \multicolumn{4}{|c|}{ Balancing process } \\
\hline & $\begin{array}{l}\text { Process } \\
\text { Name } \\
\end{array}$ & \begin{tabular}{|c|} 
Process \\
No. \\
\end{tabular} & Cap/hr & $\begin{array}{l}\text { Balanced } \\
\text { Capacity }\end{array}$ & $\begin{array}{l}\text { Process } \\
\text { Name } \\
\end{array}$ & $\begin{array}{l}\text { Process } \\
\text { No. } \\
\end{array}$ & Cap/hr & $\begin{array}{l}\text { Balanced } \\
\text { Capacity }\end{array}$ \\
\hline \multirow[t]{2}{*}{1} & $\begin{array}{lrr}\text { Back } & \text { seam } & \text { stitching } \\
\text { and } & \text { Upper } & \text { quarter } \\
\text { stitching } & \end{array}$ & 2 & 720 & 753 & $\begin{array}{|lr|}\text { Stamping } & \text { on lining } \\
\text { and } & \text { Re-enf } \\
\text { attachment } & \text { on } \\
\text { counter } & \\
\end{array}$ & 1 & 786 & 753 \\
\hline & Remarks: & \multicolumn{7}{|c|}{ Process \# 1 can work for $7.38 \mathrm{hr}$ and share work withprocess \# 2 for last $22 \mathrm{~min}$. } \\
\hline \multirow[t]{2}{*}{2} & $\begin{array}{l}\text { Foam attachment on } \\
\text { vamp }\end{array}$ & 4 & 728 & 760 & $\begin{array}{|lr|}\text { Lining } & \text { quarter } \\
\text { stitching } & \text { and } \\
\text { Hammering } & \\
\end{array}$ & 3 & 807 & 775 \\
\hline & Remarks: & \multicolumn{7}{|c|}{ Process \# 3can work for $7.39 \mathrm{hr}$. and share work with process \# 4 for last $21 \mathrm{~min}$. } \\
\hline \multirow[t]{2}{*}{3} & $\begin{array}{l}\text { Lining attaching on } \\
\text { upper and lining } \\
\text { attaching on apron }\end{array}$ & 7 & 739 & 755 & $\begin{array}{l}\text { Foam attaching } \\
\text { on apron }\end{array}$ & 5 & 776 & 760 \\
\hline & \begin{tabular}{|l|l|} 
Remarks: & \\
\end{tabular} & \multicolumn{7}{|c|}{ Process \# 5 can work for $7.49 \mathrm{hr}$. and share work withprocess \# 7 for last $11 \mathrm{~min}$. } \\
\hline \multirow[t]{2}{*}{4} & $\begin{array}{l}\text { Glue app. on quarter } \\
\text { lining }\end{array}$ & 6 & 718 & 751 & $\begin{array}{ll}\text { Vamp re-cut and } \\
\text { Apron }\end{array}$ & 8 & 789 & 756 \\
\hline & Remarks: & \multicolumn{7}{|c|}{ Process \# 8 can work for $7.38 \mathrm{hr}$. and share work with process \# 6 for last $22 \mathrm{~min}$. } \\
\hline \multirow[t]{2}{*}{5} & $\begin{array}{l}\text { Lasting margin stitch } \\
\text { (vamp) }\end{array}$ & 9 & 725 & 760 & Marking on vamp & 10 & 795 & 760 \\
\hline & Remarks : & \multicolumn{7}{|c|}{ Process \# 10can work for $7.37 \mathrm{hr}$. and share work with process \# 9 for last $23 \mathrm{~min}$. } \\
\hline \multirow[t]{2}{*}{6} & $\begin{array}{l}\text { Counter stiffener and } \\
\text { lining attach }\end{array}$ & 11 & 734 & 757 & \begin{tabular}{|l|l} 
Trimming & \\
\end{tabular} & 13 & 787 & 764 \\
\hline & \begin{tabular}{|l|l|} 
Remarks : & \\
\end{tabular} & \multicolumn{7}{|c|}{ Process \# 13 can work for $7.45 \mathrm{hr}$. and share work with process \# 11 for last $15 \mathrm{~min}$. } \\
\hline \multirow[t]{2}{*}{7} & $\begin{array}{|lll|}\text { Elastic } & \text { stitch } & \text { on } \\
\text { quarter } & & \\
\end{array}$ & 15 & 701 & 755 & $\begin{array}{l}\text { Counter stitch with } \\
\text { vamp }\end{array}$ & 12 & 814 & 760 \\
\hline & Remarks: & \multicolumn{7}{|c|}{ Process \# 12 can work for $7.23 \mathrm{hr}$. and share work with process \# 15 for last $37 \mathrm{~min}$. } \\
\hline \multirow[t]{2}{*}{8} & $\begin{array}{l}\text { Thread burning and } \\
\text { cleaning }\end{array}$ & 17 & 684 & 751 & Apron stitch & 16 & 822 & 755 \\
\hline & \begin{tabular}{|l|l|} 
Remarks : & \\
\end{tabular} & \multicolumn{7}{|c|}{ Process \# 16can work for 7.14hr. and share work with process \# 17 for last 46min. } \\
\hline \multirow[t]{2}{*}{9} & $\begin{array}{l}\text { Counter molding and } \\
\text { Vamp zigzag stitch }\end{array}$ & 14 & 733 & 756 & Bind tape attaching & 18 & 784 & 761 \\
\hline & \begin{tabular}{|l|l|l} 
Remarks : & \\
\end{tabular} & \multicolumn{7}{|c|}{ Process \# 18can work for $7.45 \mathrm{hr}$. and share work with process \# 14 for last $15 \mathrm{~min}$. } \\
\hline \multirow[t]{2}{*}{10} & $\begin{array}{l}\text { Thread burning and } \\
\text { cleaning }\end{array}$ & 21 & 720 & 760 & Bind stitching & 19 & 810 & 770 \\
\hline & Remarks : & \multicolumn{7}{|c|}{ Process \# 19 can work for $7.33 \mathrm{hr}$. and share work with process \# 21 for last $27 \mathrm{~min}$. } \\
\hline \multirow[t]{2}{*}{11} & Strap stitch one & 23 & 685 & 754 & Strap Folding & 22 & 820 & 751 \\
\hline & Remarks : & \multicolumn{7}{|c|}{ Process \# 22can work for $7.11 \mathrm{hr}$. and share work with process \# 23 for last $49 \mathrm{~min}$. } \\
\hline
\end{tabular}

Table 3. Labor productivity and Line Efficiency after line balancing.

\begin{tabular}{|c|c|c|}
\hline \multicolumn{2}{|c|}{ Total Output Per Day $=$} & 750 \\
\hline Total Manpower & $=$ & 32 \\
\hline Working Time & $=$ & 480Minutes \\
\hline S.A.M & $=$ & 20 \\
\hline \multicolumn{2}{|c|}{ Labor Productivity $=$} & 23.44 \\
\hline \multicolumn{2}{|c|}{ Line Efficiency $\%=$} & 87.6 \\
\hline
\end{tabular}

